\title{
Erro médico: uma análise de casos no Tribunal de Justiça do Estado da Paraíba
}

\section{Eduardo Uchôa Guerra Barbosa}

Programa Regional de Pós-Graduação em Desenvolvimento e Meio Ambiente. Centro de Ciências Exatas e da Natureza. Universidade Federal da Paraíba. Campus I. João Pessoa-PB, Brasil (CEP 58051-900). E-mail: eduardouchoa@hotmail.com.

Resumo. A relação médico-paciente existe há milhares de anos. 0 propósito dos médicos é tratar dos vários tipos de problemas relacionados à saúde e fazer com que as pessoas tenham uma vida longa e saudável, porém, por serem humanos, estão suscetíveis a erros. Tais erros podem causar diversos problemas à saúde, sejam eles permanentes ou não, ou até mesmo a morte. Por essa razão, médicos devem ser responsabilizados nas esferas civil, penal e administrativa pelo dano causado aos pacientes. Os 47 casos foram coletados junto ao Tribunal de Justiça do Estado da Paraíba, havendo condenação em 28 deles. 0 maior número de casos foi constatado em 2005.

Palavras-chave: Erro médico; Saúde; Pacientes; Estado da Paraíba; Brasil.

Abstract. Medical error: An analysis of cases at the Court of Justice of the State of Paraíba. The doctor-patient relationship has existed for thousands of years. The purpose of the doctors is to treat the many kinds of problems related to the health and make sure people have a long and healthy life, however, because they're humans, they are susceptible to mistakes. Such errors can cause many health problems, whether they are permanent or not, or even death. For this reason, doctors must be held responsible in the civil, criminal and administrative spheres for the damage caused to the patients. The 47 cases were collected in the Justice Court of the State of Paraíba, with 28 of them being convicted. The majority of the cases were detected in the year of 2005 .

Keywords: Medical error; Health; Doctor-patient relationship; State of Paraíba; Brazil.

\section{Introdução}

A medicina vem evoluindo muito nesses últimos anos. Diversas novas tecnologias são criadas para melhor atender aos pacientes, além de proporcionar maior conforto, segurança e probabilidade de sucesso nos tratamentos. Inúmeras vidas foram salvas devido a novos medicamentos, cirurgias, dentre outras formas de atendimento médico.

Contudo, médicos também são propensos a errar, seja por meio de uma ação ou por uma omissão. Tais erros advêm, principalmente, de imperícia, 
negligencia ou imprudência. Quando isso ocorre, pessoas podem sofrer diversos danos, que podem variar de temporários a permanentes, ou até mesmo levar a óbito.

É importante frisar que erro médico difere de riscos inerentes a um tratamento ou medicamento. Há sempre o risco do paciente não suportar uma cirurgia devido a seu próprio estado de fragilidade ou pelo avanço da doença, possuir reação alérgica a algum medicamento que não conhecia ou não conseguir mais resistir a alguma enfermidade grave.

Quando o dano advindo do erro médico é irreparável, isso causa diversos problemas para o paciente que terá que conviver com a nova situação para o resto de sua vida, além de ter que realizar gastos com diversas formas de tratamentos. Porém, mesmo que o dano seja reparável, há toda a problemática da questão do desconforto que o paciente vai ter que sofrer até que o dano seja corrigido.

Por essa razão, esta temática deve ser estudada a fim de se verificar situações que realmente se tratam de erro médico e quais as consequências de cada caso. Contudo, deve-se ressaltar, que pela importância do bem administrado por esses profissionais da saúde, a vida, que deve haver punições quando há erro médico.

\section{Formas de erro médico}

Um erro médico pode ser evitável ou inevitável. 0 erro evitável é aquele que o médico possuía plenas condições de evitar, mas que por imprudência, negligência ou imperícia ele não evita, dessa forma tornando-se responsável pelo resultado. Já o erro inevitável é aquele que ocorre devido a limitações nos próprios equipamentos ou técnicas conhecidas, portanto, neste caso, o médico não seria penalizado pelo resultado negativo (Gomes, 2009).
Nunes (2004: 15) detalha a matéria ao explicar que imperícia médica é quando há uma falta de conhecimento ou até de preparo por parte do profissional. A imprudência ocorre por ação ou omissão quando não é feito esclarecimentos ao paciente acerca dos riscos ou quando é realizado algum procedimento sem a devida fundamentação científica. E, quanto à negligência, ela ocorre quando o médico age sem interesse ou até com descaso para com seu paciente.

No que tange aos erros por tratamento, há a questão da imperícia médica que faz com que o profissional escolhesse agir de uma forma que não condizia com o problema real do paciente (Fávero, 1945; Gomes, 2009). E no que se refere ao erro de dosagem de medicamentos, há a questão da falta de conhecimento técnico adequado para analisar a situação, configurando-se como imprudência por prescrever uma dosagem errada de algum medicamento.

Nunes (2004: 12-13) elenca também fatores de risco que podem levar a um médico a cometer erros:

1 - Péssimas condições para pleno e bom exercício da medicina, variando desde a falta de recursos materiais até o excesso de pacientes diante de um número de profissionais disponíveis para o atendimento de toda a massa que busca orientação e aconselhamento.

2 - Formação médico-universitária inapropriada ou deficiente diante do péssimo sistema de ensino vigente em algumas instituições do país, bem como a acomodação do profissional que não procura especializar-se e atualizar se cada vez mais em sua área profissional.

3 - Interesses meramente comerciais, onde o paciente é visto como um polpudo cheque ou notas de dinheiro seja por iniciativa isolada do médico $\mathrm{m}$ especialidades rendosas ou em conjunto por meio de cooperativas 
ou empresas médicas comprometidas com o lucro.

4 - 0 baixo nível salarial dos profissionais empregados de empresas públicas.

5 - 0 alto nível de stress diante da realidade socioeconômica do país e das péssimas condições de trabalho e emprego

6 - Distorções e desorganização do sistema de saúde pública, que acarretam complexas implicações de ordem ética e legal.

7 - A falta de compromisso do médico.

8 - Precária fiscalização do exercício profissional por parte das entidades de classe, que nem sempre procuram ajustar o profissional às normas éticas que regem seu ofício.

Vale também realizar uma diferenciação entre erro e ignorância acerca de um fato. Erro trata da errônea percepção sobre um fato ou coisa, enquanto que, na ignorância, há a falta de conhecimento acerca de uma situação. $\mathrm{Na}$ medicina, essas duas formas são puníveis (Moraes, 1996).

Moraes (1996) também explica que não apenas há casos de erro juntamente com sua responsabilização na área mercantilista da medicina. Mesmo que haja "prestações benévolas", ou seja, gratuitas, o profissional deve responder da mesma forma se o atendimento fosse remunerado, já que a gratuidade não isenta de responsabilidade.

\section{Responsabilidade}

A legislação brasileira tratou de antever situações em que os médicos devam ser responsabilizados pelos danos causados aos pacientes de forma objetiva, ou seja, não importando se agiu de forma culposa ou dolosa. 0 que se modificaria apenas seria a gravidade da punição, mas não há isenção de pena desde que haja um nexo de causalidade entre a conduta faltosa do médico e o dano.

Uma das primeiras leis que regulamentaram a profissão do médico foi o Código de Hammurabi, entre os séculos XVIII e XVII a.C., que contemplava três artigos:

Artigo 215: se um médico trata alguém de uma grave ferida com a lanceta de bronze e o cura ou se ele abre a alguém uma incisão com a lanceta de bronze e o olho é salvo, deverá receber dez siclos.

$[\cdots]$

Artigo 218, se um médico trata alguém de uma grave ferida com a lanceta de bronze e o mata, ou lhe abre uma incisão com a lanceta de bronze e o olho fica perdido, deverse-lhe-á cortar as mãos.

\section{$[\cdots]$}

Artigo 219, se o médico trata o escravo de um liberto de uma ferida grave com uma lanceta de bronze e o mata, deverá dar escravo por escravo.

Na Antiga Roma, também existiam leis que puniam os erros médicos, porém a legislação era tão rigorosa que causava temor e afastava pessoas da profissão. A situação chegou a tal ponto que tiveram que tornar escravos médicos e até "importar" profissionais de outras regiões (Moraes, 1996).

Hoje, as leis são mais brandas, mas elas ainda procuram punir de forma adequada aqueles que incorrem em erro médico, porém deve-se também ressaltar que não são apenas os médicos que são regidos por essas regras. Assim como diz o art. 11, do Decreto-Lei no 20.931/1932 (Brasil, 1932):

Art. 11 Os médicos, farmacêuticos, cirurgiões dentistas, veterinários, enfermeiros e parteiras que cometerem falta grave ou erro de ofício, poderão ser suspensos do 
exercício da sua profissão pelo prazo de seis meses a dois anos, e se exercem função pública, serão demitidos dos respectivos cargos (Brasil, 1932).

Assim, são diversos profissionais da saúde que devem realizar suas condutas de forma cuidadosa para evitar incorrer em erro. Em conformidade com esse entendimento, há os art. 186, do Código Civil (Brasil, 2002), que diz: "aquele que, por ação ou omissão voluntária, negligência ou imprudência, violar direito e causar dano a outrem, ainda que exclusivamente moral, comete ato ilícito". Há também os arts. 402 e 403, ambos do Código Civil, que tratam do lucro cessante, que ocorre, basicamente, quando o dano impossibilita o paciente de trabalhar, impedindo o seu próprio sustento e o de sua família, cabendo, também indenização acerca deste problema (Moraes, 1996).

Um juiz pode se usar de peritos para analisar cada caso, pois se trata de uma área que provavelmente não é de conhecimento técnico do magistrado. Porém, o art. 436, do Código Civil traz: "o Juiz não está adstrito ao laudo pericial, podendo formar a sua convicção com outros elementos ou fatos provados nos autos" (Brasil, 2002). Desta forma, o juiz não está obrigado a seguir o laudo pericial, pois ele pode apresentar falhas e o magistrado pode se usar de outros meios para chegar à sua decisão (Nunes, 2004: 32-33)

Na esfera penal, nos arts. 18, 133, 135 do Código Penal (Brasil, 1940):

Art. 18. Diz-se o crime:

I - doloso, quando o agente quis o resultado ou assumiu o risco de produzi-lo.

II - culposo, quando o agente deu causa ao resultado por imprudência, negligência ou imperícia.

\section{[...]}

Art. 133. Abandonar pessoa que está sob seu cuidado, guarda, vigilância ou autoridade, e, por qualquer motivo, incapaz de defender-se dos riscos resultantes do abandono:

Pena - detenção, de seis meses a três anos.

\section{[...]}

Art. 135. Deixar de prestar assistência, quando possível fazê-lo sem risco pessoal, à criança abandonada ou extraviada, ou à pessoa inválida ou ferida, ao desamparo ou em grave e iminente perigo; ou não pedir, nesses casos, o socorro da autoridade pública:

Pena - detenção, de um a seis meses, ou multa.

Parágrafo único. A pena é aumentada de metade, se da omissão resulta lesão corporal de natureza grave, e triplicada, se resulta a morte (Brasil, 1940).

Além disso, pode haver uma situação onde haja lesão corporal, seja ela leve, grave ou seguida de morte, enquadrando-se no dispositivo do art. 129, também do Código Penal (Brasil, 1940). Também é preciso que o autor da ação prove a materialidade do dano, o prejuízo efetivo e o nexo causal da ação médica e o dano, segundo o art. 333, do Código de Processo Civil (Lei $\mathrm{n}^{\mathrm{o}}$ 13.105/2015) (Brasil 2015). Porém, há casos em que pode haver inversão do ônus da prova, quando houver verossimilhança das alegações e hipossuficiência, não apenas material, mas também técnica, de produzir provas, como assim trata o art. 6을 inciso VIII, do Código de Defesa do Consumidor (Lei no 8.080/1990) (Brasil, 1990).

Contudo, não apenas há a questão de responsabilidade legal. Há também a questão ética também. A questão ética começou com o filósofo grego Hipócrates, que criou um juramento para os médicos e o propagou na sua escola. Em concordância, hoje, os Conselhos de Medicina e o Código de Ética tentam assegurar que haja um bom relacionamento entre pacientes $\mathrm{e}$ 
médicos, pois não se pode confiar plenamente na pura moral, que cada médico pode possuir diferente uns dos outros, precisando, portanto, haver um código de conduta que possa servir de coação para esses profissionais da saúde (Nunes, 2004: 19-20).

Desta forma, pode-se dizer que a responsabilidade médica engloba a esferas penal, civil e administrativa. Sendo esta última esfera acerca das punições auferidas pelos Conselhos de Medicina federais ou estaduais, a depender do caso, além de que a própria administração pública pode investigar e punir os profissionais da saúde que atuem no serviço público (Moraes, 1996), inclusive com base Lei no 8.112/1990 (Brasil, 1990).

Entretanto, Moraes (1996) complementa ao afirmar que mesmo havendo um erro médico, mas se ele não causar nenhum dano ou prejuízo, não há o que se falar em punição, pois deve haver uma relação direta entre a ação ou omissão médica e o dano sofrido para que possa haver responsabilidade.

\section{Casos no Estado da Paraíba}

No Estado da Paraíba, essa prática também ocorre com certa frequência. Contudo, os resultados desses processos não são uniformes em vista de que nem sempre o paciente possui razão ou até mesmo porque ele não conseguiu juntar as provas necessárias. As referidas ações foram informadas pelo Tribunal de Justiça da Paraíba.

0 primeiro caso refere-se a uma Apelação Civil de no 075.2002.0029338/001 que tratou de uma cirurgia de catarata que o autor fez e que, segundo ele, pirou o estado de saúde de seus olhos. Contudo, durante a perícia, chegou-se a conclusão de que não houve o nexo de causalidade entre a cirurgia e o estado atual dos olhos do autor, pois não se chegou a conclusão de que o dano foi devido a cirurgia, mas sim, devido a própria atrofia congênita que o autor já possuía desde a infância. Esse processo foi considerado improcedente.

A Apelação civil de $\mathrm{n}^{\mathrm{o}}$ 200.2006.059262-9/001 foi sobre o erro de um exame de ultrassonografia realizado no CEDRUL (Centro de Diagnósticos por Imagens). Em primeiro grau, a autora da ação pediu indenização por danos morais e perdeu pela falta de provas. Porém, neste recurso, o desembargador proferiu decisão em favor da apelante em vista de considerar suficientes os argumentos e provas trazidas pela autora, principalmente porque se tratou de um erro sobre a existência de nódulos, fazendo com que a autora quase se submetesse a uma cirurgia desnecessária. 0 relator condenou o CEDRUL a R\$ 10.000,00.

A Apelação Civil de no 200.2005.033845-4/001 versou sobre reparação de danos materiais e morais sobre uma cirurgia de cunho reparador e estético, pois a autora da inicial adquiriu uma infecção bacteriana e sofreu danos. Em primeiro grau, o juiz considerou parcialmente procedente a ação, negando o dano moral por falta de provas, mas julgou procedente o dano material no valor de $\mathrm{R} \$ 20.000,00$. 0 promovido foi o Hospital da UNIMED de João Pessoa que alegou ilegitimidade passiva nesta apelação alegando a responsabilidade ser subjetiva do médico que realizou a cirurgia. Contudo, o desembargador da ação concluiu que a UNIMED possuía responsabilidade objetiva sobre a infecção bacteriana que a autora sofreu e que não ficou provado se o médico agiu com imprudência, negligência ou imperícia (que caracterizariam a responsabilidade subjetiva). Portanto a decisão da indenização ficou mantida.

Em conformidade com o caso anteriormente relatado, a Apelação Cível no 200.2001.124.429-6/003 também trata da responsabilidade do Hospital da UNIMED em João Pessoa, pois ele é um prestador de serviços, logo não há o que se falar em culpa subjetiva para ele, mas sim objetiva, bastando somente a comprovação do nexo de causalidade do 
ato e da consequência. Além do Hospital da UNIMED, que não foi considerado como parte no primeiro grau, a Clínica Ortopédica e Traumatológica de João Pessoa Ltda foi condenada pelo pagamento de $\mathrm{R} \$ 3.000$ pelos danos estéticos sofridos pela autora da inicial e $\mathrm{R} \$ 3.000,00$ por danos morais no $1^{\circ}$ grau. Porém, após a apelação, o desembargador concluiu pela presença do Hospital no polo passivo e proferiu uma indenização total de $\mathrm{R} \$ 30.000,00 \mathrm{a}$ ser paga solidariamente pelos membros do polo passivo para a autora da inicial a titulo de indenização.

$\mathrm{Na}$ Apelação Civil de no 200.2007.777829-4/001, novamente a UNIMED de João Pessoa recorre alegando não ser legitima para configurar no polo passivo no caso em que um médico proferiu um medicamento para a autora que era alérgica, alegando a culpa ser subjetiva e exclusiva do médico. Contudo, novamente, foi considerado o posicionamento de que como a UNIMED de João Pessoa é uma prestadora de serviços, ela possui responsabilidade objetiva e foi condenada ao pagamento de $\mathrm{R} \$ 15.000,00$ a título de dano moral.

A Apelação Cível de $n^{\circ}$ 073.2010.003.106-8/001 tratou de indenização por danos materiais e morais porque a filha da autora estava grávida, apresentando também quadro de pré-eclâmpsia (doença gestacional), e após ser atendida no Hospital Universitário Lauro Wanderley (HULW) foi levada a óbito por causa de complicações no tratamento, morrendo também o filho recém-nascido. A autora ganhou em primeira instância o valor de $\mathrm{R} \$ 100.000,00$ em valor de dano moral e material, além de pensão mensal no valor de $20 \%$ do salário-mínimo em favor da autora. 0 município recorreu por meio desta apelação alegando culpa exclusiva da vítima por não ter feito os exames solicitados e ter retornado ao HULW quando seu quadro de pressão alta se agravou, porém o desembargador decidiu que o Estado, por ser prestador de serviço, possui responsabilidade objetiva segundo o art. $37, \S 6^{\circ}$, da Constituição Federal de 1988 (CF/88). 0 desembargador decidiu o provimento parcial do recurso, mantendo a indenização de $\mathrm{R} \$ 100.000,00$, mas denegando o pedido de pensão, pois não havia provas de dependência econômica da autora para com sua filha falecida.

No caso da Apelação Cível no 200.2005.068.865-0/002 o autor teve sua inicial considerada improcedente em primeira instância, por não ficar provado nexo de causalidade, ao pedir danos materiais e morais em face de erro médico cometido pelo Pronto Socorro Central de Fraturas Ltda., que apenas realizou exames no autor. Tal erro tratou da remoção de um tumor de seu braço direito, no Hospital Newton Lacerda, que causou paralisia nesse membro. Contudo, tal clínica agiu com imprudência e insistiu no paciente em continuar om as fisioterapias após um segundo procedimento no seu braço, o que agravou ainda mais seu quadro. 0 desembargador considerou justa a indenização de R\$113.520,00.

A Apelação Cível $\mathrm{n}$ 응 001.2005.014945-7 foi sobre um recurso impetrado pelo Hospital Antônio Targino Ltda. e um espólio do médico falecido contra uma sentença que julgou favorável ação de indenização por danos materiais e morais decorrentes de erro médico, havendo fixação, na primeira instância, de indenização no valor de R\$ $20.000,00$ a ser paga pelo hospital e $\mathrm{R} \$$ $15.000,00$ pelo médico. Na apelação, o médico não provou que agiu com zelo e cuidados, pois ficou provado que o paciente chegou em estado emergencial e houve uma demora excessiva para que ele fosse atendido. Assim, ficou provada a responsabilidade de ambos os apelantes, havendo denegação de seu recurso, mantendo os valores da inicial.

A Apelação Cível e o Recurso Adesivo de no 200.2005.069328-8/001 tratou de recurso impetrado pelo médico após decisão de primeiro grau conferindo indenização de $\mathrm{R} \$ 20.000,00$ por danos materiais e $\mathrm{R} \$ 10.000,00$ por 
danos morais, acrescidos de juros de mora de $1 \%$ ao mês desde o fato danoso pelos danos causados após uma cirurgia reparadora no nariz da autora da inicial. No recurso o médico alega que não deveria caber dano moral, pois os danos estéticos que a paciente sofreu foram corrigidos sem ônus algum para ela. 0 desembargador decidiu por acolher o recurso, pois ficou provado que se tratou de um pedido de natureza ultra petita pois o médico reparou o dano no nariz da autora da inicial não havendo erro médico nesta situação, mantendo-se apenas a indenização por dano material.

$$
\text { Apelação Cível no }
$$

200.2002.373329-4/001 tratou do caso de uma cirurgia de redução de estômago que resultou em morte no Hospital Santa Lúcia Ltda. No primeiro grau, o juiz decidiu que os médicos eram isentos de culpa e que a responsabilidade recaiu apenas no hospital, pela deficiência no serviço, tendo que pagar $\mathrm{R} \$ 150.000,00$ além de pensão para o filho da falecida até ele completar 25 anos no valor de $2 / 3$, que percebia $\mathrm{R} \$ 243,41$, da remuneração percebida pela falecida. Os parentes da vítima entraram com a apelação, pois alegam que a equipe médica agiu com culpa para o resultado. o hospital, por sua vez, alegou que apenas cedia espaço para os médicos, não havendo qualquer vínculo entre ele $\mathrm{e}$ os pacientes. A obrigação médica é de meio e não resultado, ou seja, o médico deve agir da melhor forma possível e sem agir com culpa ou dolo durante o tratamento dos pacientes, pois, se agir de tal forma, o médico não será responsabilizado mesmo que o paciente sofra danos ou venha a óbito. Assim, o desembargador decidiu que os médicos não poderiam ser responsabilizados, contudo afirmou que o hospital possuía responsabilidade objetiva e apenas se isentaria de responsabilidade se houvesse culpa exclusiva da vítima; fato exclusivo de terceiro; ausência de nexo causal; caso fortuito ou força maior, o que não foi o caso. Assim, foi mantida a pensão, contudo devido a condição financeira do hospital, que estava com o serviço de UTI sem funcionar, e os princípios da razoabilidade, proporcionalidade e do não enriquecimento ilícito, foi reduzida a indenização para $\mathrm{R} \$$ $50.000,00$.

A Apelação Cível e Remessa Oficial $\quad \mathrm{n}$ - 200.2004.030072-1/001 abordou o caso do recurso de uma sentença de primeiro grau que condenou o Município de João pessoa ao pagamento de $R \$ 150.000,00$ a título de indenização, além de pensão vitalícia de 3 salários-mínimos pela paralisia cerebral sofrida por uma criança em um parto. 0 Ministério Público chegou a dar um parecer pela manutenção do valor da indenização. 0 Município alegou não haver nexo de causalidade entre o dano sofrido pela criança e o tratamento, porém ficou provado que houve descuidos médicos. 0 relator do processo decidiu por manter tanto o valor da indenização quanto o da pensão vitalícia.

No que tange à Remessa Oficial e Apelação Cível de no 200.1999.0459931/001, na decisão de primeira instância, foi deferido pensão vitalícia de 1 saláriomínimo mensal além de $\mathrm{R} \$ 20.000,00$ a título de indenização pelo erro médico, que causou paralisia cerebral por falta de oxigenação na vítima que teve de ser representada em juízo, contra o Estado da Paraíba. Contudo o autor da inicial apelou pedindo pensão de 8 saláriosmínimos e R\$200.000,00 a título de indenização. O Estado não apresentou contrarrazões neste caso. Após analisar os fatos, o desembargador decidiu por majorar a pensão para 3 saláriosmínimos mensais e a indenização para $\mathrm{R} \$ 100.000,00$.

A Apelação Cível de $\mathrm{n}$ o 001.2000.016694-0/001 trata de um recurso para modificar a sentença de primeiro grau que julgou improcedente a indenização por danos morais e materiais decorrente de erro médico, acerca da colocação errada de uma prótese, devido à ausência de prova da culpa do médico. 0 Ministério Público opinou pela reforma da sentença de 
forma parcial para ser fornecida a indenização de $\mathrm{R} \$ 20.000,00$. Após analisar as provas, o relator chegou a conclusão que os danos sofridos pela parte apelante não foram decorrentes de nenhuma das modalidades de culpa (imprudência, negligência e imperícia), então não há responsabilidade do médico, pois, como antes mencionado, sua responsabilidade é pelo meio e não do resultado. Portanto o relator julgou pelo mantimento da sentença de primeiro grau.

A Remessa Oficial de $\mathrm{n}^{\circ}$ 001.2008.022690-3/001 foi julgada após uma sentença de primeiro grau que condenou o Estado da Paraíba ao pagamento de $\mathrm{R} \$ 6.000,00$ a título de dano material e $\mathrm{R} \$ 20.000,00$ por danos morais. A remessa oficial não é um recurso, mas ume exame de ofício no caso de decisão em desfavor da administração pública. 0 autor da inicial sofreu um acidente automobilístico e sofreu uma fratura na mandíbula e foi tratado por médico ligado a rede pública da Paraíba, de forma que foi considerada errônea por outro médico em Recife, o que fez o autor gastar com cirurgias. $0 \mathrm{~A}$ desembargadora, por fim, decidiu manter a decisão de primeiro grau.

A Apelação Cível de $\mathrm{n}^{\text {o }}$ 001.2006.011615-7/002 aborda um caso de médico do Hospital Antônio Targino Ltda. que não realizou exames de sensibilidade de anestesia e quando o paciente foi anestesiado sofreu choque anafilático e foi levado a óbito, sendo o autor da inicial o genitor do paciente. A sentença de primeiro grau condenou o hospital ao pagamento de $\mathrm{R} \$ 69.750,00$, o que levou a ambas as partes recorrerem inconformadas. 0 hospital tentou realizar uma denunciação a lide para o Sistema Único de Saúde (SUS) pois os médicos seriam vinculados a este e não ao Hospital Antônio Targino Ltda, contudo a desembargadora desconsiderou a tese, pois o referido hospital tem o dever objetivo de fiscalizar a qualidade do serviço médico prestado. A desembargadora decidiu pelo não provimento de ambos os recursos e manteve a indenização de primeiro grau por considerar justa.

Apelação Cível $\mathrm{n}^{\text {o }}$ 098.2009.001053-3/001 foi impetrada pelo Estado da Paraíba após a condenação em primeiro grau no valor de $\mathrm{R} \$ 51.000 .00$ para cada um dos médicos, ligados ao referido ente, o que totaliza $\mathrm{R} \$ 102.000,00$ devido a um erro médico. 0 Estado alega que a decisão de primeiro grau deve ser reformada por não possuir nexo de causalidade entre o falecimento da filha dos autores além de que não poder haver o efeito da revelia contra o Estado. 0 relator decidiu que de fato os efeitos da revelia não poderiam afetar o Estado da Paraíba de acordo com o art. 320, II, do CPC. O relator deu provimento ao recurso do Estado da Paraíba e mandou os autos de volta para o primeiro grau para serem julgados novamente.

O caso da Apelação Cível de no 001.2005.015075-2/001 tratou de um recurso impetrado pelo médico que realizou uma cirurgia em uma paciente, que resultou em danos estéticos e teve decisão em primeiro grau condenando tal médico ao valor de $\mathrm{R} \$ 32.965,00$. 0 médico alega que usou todas as técnicas corretas e que não incorreu em imperícia na lipoescultura corporal realizada. Pelo fato da cirurgia no caso em tela ser embelezadora, ela tem como objetivo o resultado e não o meio empregado existindo assim, a responsabilidade do médico. Contudo, o relator decidiu ser justo reduzir a indenização para $\mathrm{R} \$$ $30.225,00$.

A Apelação Cível no 001.2005.023518-1/002 tratou de uma suposta negligência no atendimento médico, no Hospital Antônio Targino Ltda., de paciente acometido de acidente vascular cerebral (AVC), o que levou o paciente ao óbito. No primeiro grau, a decisão proferida pelo juiz foi pelo improcedência da inicial pela não comprovação do nexo de causalidade da atividade médica prestada e o AVC. A representante do falecido não possuiu 
êxito em provar o nexo de causalidade no recurso e o magistrado enfatizou que a atividade médica tem como objetivo o meio e não o resultado, logo julgou pelo não provimento do recurso.

No caso da Apelação Cível de no 200.2005.072.654-2/001 houve uma discussão acerca do erro de um diagnóstico médico de ultrassonografia pélvica transvaginal no Centro de Diagnóstico por Imagem Lautônio Loreiro e Djalma Marques Neto (CENTRIMAGEM). Segundo a paciente, houve uma falha porque em um primeiro exame foi afirmado que não havia nenhuma irregularidade na paciente, porém ela se queixava de dor e em um segundo exame, 10 dias depois na clínica Tomosom Tomografia Computadorizada e Ultrassonografia, foi constatado uma inflamação nos ovários. 0 relator afirmou em concordância com outros processos já mencionados de que a responsabilidade dos profissionais médicos liberais é de caráter objetivo, enquanto que a da clínica é objetiva, de acordo com o art. 14, do Código de Defesa do Consumidor (Lei $\mathrm{n}^{\mathrm{o}}$ 8.080/1990) (Brasil, 1990). Segundo o perito, não houve erro na análise $\mathrm{e}$ procedimento do primeiro exame e, segundo ele, houve a constatação do problema na segunda clínica porque ele foi feito 10 dias depois o que permitiu o quadro a ficar visível para o exame. Portanto, o relator decidiu pelo não provimento do apelo, pois ficou provado que não houve configuração de erro.

\section{A Remessa Oficial e a Apelação}

Cível de $\mathrm{n}^{-}$200.2005.031194-9/002 tratou de outro caso de erro médico impetrado contra o Estado da Paraíba. A autora a ação diz sofrer danos na perna direita ao ser tratada no Hospital de Trauma da Capital e conseguiu, na primeira instância, a condenação do estado em R $\$ 15.000,00$ e uma pensão vitalícia mensal de um salário-mínimo, porém ela recorreu buscando uma indenização que se enquadre melhor com o dano por ela sofrido. Ambos o Estado e o médico alegam ilegitimidade passiva, sendo a alegação do primeiro porque não possuiu culpa subjetiva e o segundo por ser apenas um funcionário do Estado e que agiu conforme os procedimentos cirúrgicos adequados. 0 relator do processo decidiu pela ilegitimidade passiva do médico porque o dever de indenizar é do ente que o contratou. Por fim, com a mesma fundamentação antes mencionada, o Estado possui responsabilidade objetiva, sendo mantida a indenização e aumentando a pensão para 2 salários-mínimos mensais. Quanto a Apelação Cível no 001.2004.011880-2/003, ela foi promovida pelo município de Campina Grande e o médico da autora da inicial, que alegou ter que se submeter a dois procedimentos cirúrgicos devido a um erro de diagnóstico. A sentença que eles recorrem condenou o município ao pagamento de $\mathrm{R} \$ 15.000,00$ de indenização por danos morais e materiais. 0 médico alegou que não arguiu com culpa e que teve cerceamento de defesa e o município se defende ao constar que não houve erro médico e que a autora é quem devia provar que houve negligência, imprudência ou imperícia médica, além do que toda a indenização deveria ser paga pelo médico. 0 desembargador decidiu que o médico, por ser um agente público, responde de forma subjetiva e o município de forma objetiva, além de julgar que são eles que devem provar que realizaram 0 procedimento médico de forma correta, de acordo com o art. 6ํㅡ, VIII, do Código de Defesa do Consumidor. Também ficaram provados o efetivo dano e culpa do médico. Contudo, o relator julgou que a quantia fixada em primeira instância foi exagerada, fixando, portanto, a quantia de $R \$ 10.000,00$, sendo $R \$ 7.000,00$ para ser pago pelo médico e $\mathrm{R} \$ 3.000,00$ pelo município.

A Remessa Oficial e a Apelação Cível de no 200.2007.741.303-3/001 foram interpostos em favor do município de João Pessoa contra a autora da inicial que pleiteou danos materiais e morais em decorrência de dano causado a filha 
da autora que resultou em paralisia do plexo braquial após ser atendida no Hospital Cândida Vargas. A autora da inicial ganhou em primeira instância o valor de $\mathrm{R} \$ 60.000,00$. 0 apelante alega cerceamento de defesa, já que não teve dilação probatória requerida na sua contestação, e o relator do apelo e remessa oficial entendeu justa tal alegação cassando a sentença de primeira instância e reabrindo a fase probatória.

Apelação Cível no
094.2004.000.162-3/001 tratou de um recurso interposto pelo Instituto Walfredo Guedes Pereira e um médico a ele pertencente em cima de uma decisão que os condenou ao pagamento de $\mathrm{R} \$$ $70.000,00$ em favor da autora da inicial em decorrência de uma paralisia durante uma cirurgia de hérnia de disco. 0 Instituto alega não ser cabível aplicação do Código de Defesa do Consumidor (Lei no 8.080/1990) (Brasil, 1990), porque o tratamento foi custeado pelo SUS, além de que tal paralisia foi causada por uma "mielite" e não pela cirurgia, não havendo erro médico. A autora da inicial provou o nexo de causalidade entre a conduta médica e a paralisia, enquanto que os apelantes não conseguiram provar que o dano adveio de um fato posterior independente. Ademais, pela cirurgia ocorrer em suas dependências, 0 Instituto se responsabiliza e se torna legitimado para sofrer a ação devido ao seu dever objetivo de cuidado. 0 relator decidiu pela manutenção da decisão de primeiro grau em virtude dela condizer com a dor e o dano sofridos pela paciente.

A Apelação Cível de $\mathrm{n}$ 음 200.2007.011.871-2/001 se referiu ao caso de um suposto erro de diagnóstico cometido no Hospital da UNIMED de João Pessoa com relação a uma fratura de clavícula, que não havia sido detectada no primeiro exame. A decisão recorrida condenou o hospital ao pagamento de $\mathrm{R} \$$ $7.000,00$ por danos materiais e morais. 0 hospital alega que o autor da inicial não conseguiu provar o nexo de causalidade, pois ficou provado que o autor não provou que tal fratura realmente existia na data do primeiro exame. Assim, o desembargador julgou em favor do hospital apelante.

$$
\text { Apelação Cível no }
$$

001.1998.008649-8/001 abordou o tema acerca de um erro médico que deixou o autor da inicial inválido após uma cirurgia abdominal no Hospital Antônio Targino Ltda. A sentença de primeiro grau condenou o hospital ao pagamento de $\mathrm{R} \$ 25.000,00$ reais além de uma pensão de $2 / 3$ do salário mínimo até o autor completar 65 anos de idade. 0 hospital alegou ilegitimidade passiva, pois o médico não era vinculado ao hospital, mas sim ao SUS, porém essa tese não foi aceita pelos mesmos motivos já explicados. Porém o relator decidiu que o valor fixado na primeira instância ultrapassava os limites razoáveis e por isso fixou a indenização no valor de $\mathrm{R} \$$ $15.000,00$.

Quanto a Apelação Cível de no 200.2004.006.691-8/001, ela se referiu a uma indenização por erro em uma cirurgia para tratar de um deslocamento de retina que, em primeiro grau, gerou uma indenização no valor de $\mathrm{R} \$ 7.000,00$. A clínica oftalmológica alegou prescrição porque a cirurgia ocorreu em julho de 1999 e a autora apenas entrou com ação em janeiro de 2004, contudo essa tese não foi aceita, pois prescreve-se em cinco anos a pretensão para reparação de danos causados por produtos ou serviços, de acordo com art. 27, do Código de Defesa do Consumidor (Lei ํㅡㅁ 8.080/1990) (Brasil, 1990). Além disso, os médicos não informaram à paciente que a cirurgia a qual ela se submeteu poderia causar a cegueira, logo, mesmo que tenham sido aplicadas as técnicas corretas (o que não incorre em erro médico), houve culpa médica pela falta de informação para a paciente, pois após saber dos riscos ela deveria escolher se desejaria ou não realizar a cirurgia. 0 relator do processo decidiu pela manutenção da sentença de primeiro grau. 
A Apelação Cível $\mathrm{n}^{\mathrm{o}}$ 001.2005.030539-8/001 foi um recurso interposto pela autora da inicial acerca de uma cirurgia de pieloplastia, no Hospital Antônio Targino Ltda., em que a paciente alega que houve erro e foi deixado um corpo estranho em seu rim direito, o que a fez se submeter a novo procedimento cirúrgico, no Hospital Regional de Urgência e Emergência, que resultou na perda do órgão. 0 Hospital Antônio Targino Ltda. alegou que a autora não conseguiu provar o nexo de causalidade, culpa ou dolo da cirurgia com o dano e que o suposto "corpo estranho" na verdade era um processo inflamatório. 0 juiz de primeiro grau acolheu essa tese julgando improcedente o pedido. Após analise pericial médica, restou provado que o suposto "corpo estranho" foi realmente um processo inflamatório não decorrente de erro da primeira cirurgia. Dessa maneira, o relator deste processo julgou pela improcedência do recurso, mantendo a decisão de primeiro grau.

$$
\text { A apelação Cível } \mathrm{n} \text { ㅇ }
$$

001.2001.006451-5/001 tratou de um recurso impugnado pela autora da inicial, que foi considerada improcedente no juízo de primeiro grau, tratando de um suposto erro médico que causou um lesão radicular, que provocou uma diminuição da sensibilidade na perna esquerda, durante uma cirurgia. A Clínica Pronto Socorro Infantil e Hospital Geral (Clipsi) apresentou defesa alegando que não houve nexo de causalidade entre o procedimento médico e a lesão. 0 relator, após analise pericial, chegou a conclusão que o médico não agiu com nenhuma das três formas de culpa nem havia comprovação de que a cirurgia foi a responsável pela lesão, podendo esta ter tido outra origem. Assim, o relator julgou improcedente o recurso.

A apelação Cível de no 001.2005.000.361-9/001 abordou um recurso impetrado pelo Laboratório de Análises Clínicas (LACEP) em consórcio necessário com o Laboratório Sérgio Franco Medicina Diagnóstica e pelo autor da inicial. 0 autor alega que ao fazer um concurso para a Polícia Militar, realizou um exame de sangue que teve como resultado errôneo de que ele era portador de Hepatite B, o que lhe custou a vaga no concurso. $O$ autor pediu uma indenização de 300 salários-mínimos, 150 para cada réu, além de $\mathrm{R} \$ 439,00 \mathrm{em}$ danos materiais e lucros cessantes. 0 juiz de primeira instância condenou os réus ao pagamento $R \$ 21.000,00$ por danos morais e $\mathrm{R} \$ 439,00$ pelos danos materiais, não acolhendo a indenização por danos cessantes. O LACEP alegou ilegitimidade passiva além de afirmar que não houve danos morais ou materiais, enquanto que o autor da inicial requer que a indenização por danos morais seja dobrada. Após a análise processual, o relator entendeu por manter o valor da indenização por danos morais, contudo o relator entendeu por reduzir a indenização por danos materiais do LACEP para $\mathrm{R} \$ 132,25 \mathrm{em}$ virtude da sua pequena participação para o resultado, sendo que o outro laboratório terá que pagar $R \$ 264,50$ por danos materiais, totalizando um total de $\mathrm{R} \$ 21.396,75$.

A Apelação Cível $\mathrm{n}$ 응 200.2005.043950-0/001 foi sobre um suposto erro de diagnóstico realizado por um médico vinculado ao Estado da Paraíba, no Centro de Atendimento Médico Especializado de Jaguaribe (CAME), que haveria causado danos ao autor da inicial, pois, segundo ele, ele foi diagnosticado erroneamente com hepatite e passou a tomar medicamentos que agravaram seu estado de saúde. 0 apelante também alega que após o segundo exame ficou comprovado que sua enfermidade na verdade era um quadro de gastrite. 0 autor recorreu porque o juiz de primeiro grau julgou improcedente a ação pela falta de provas que comprovassem o dano. Contudo, o apelante não apresentou nenhum documento que provasse que o primeiro médico afirmou que sua doença era hepatite e, além disso, o medicamento que ele havia tomado tem como objetivo 
apenas amenizar sintomas ligados a hepatite, não havendo efeitos colaterais reportados pelo requerente. Por estas razões, o desembargador julgou 0 recurso improcedente.

No que tange à Apelação Cível de no 200.2003.014848-6/001, foi um recurso impetrado tanto pela autora da inicial quanto pela Clinor (Clínica Ortopédica, Traumatologia e Reabilitação Ltda.). A autora alega que sofreu paralisia em membro inferior por causa de uma trombose venosa profunda, o que resultou em uma decisão de primeira instância que condenou a clínica em pagamento de $\mathrm{R} \$ 5.000,00$. A autora da inicial requer majoração da indenização, enquanto que a clínica alega não haver nexo de causalidade entre o dano e o procedimento médico. 0 desembargador entendeu que tal indenização estava equivocada, pois o juiz a quo julgou o processo não levou em conta a culpa do profissional liberal, que inexistiu. Se não houve configuração de conduta culposa nem dolosa, não houve erro médico, não podendo, assim, responsabilizar a clínica.

A Apelação Cível $\mathrm{n}$ o 200.2004.019404-1/001 tratou de um recurso impetrado pela autora da inicial que foi submetida a uma cirurgia de laqueadura de trompas sem sua permissão, o que a impossibilitou de engravidar novamente. Em sua defesa na inicial, o Município de João pessoa alegou prescrição quinquenal, pois 0 procedimento foi realizado em 1993 e falta de nexo de causalidade, assim o juiz de primeiro grau considerou improcedente a ação. 0 relator deste recurso o julgou improcedente porque a autora não trouxe nenhuma prova de que a ação ou omissão médica de alguma forma resultou no dano sofrido.

Apelação Cível $\mathrm{n}$ ㅇ
200.2003.022990-6/001 foi sobre uma paralisia cerebral causada em um recémnascido durante um parto no Hospital e Maternidade Frei Damião por médico ligado ao Estado da Paraíba. A decisão de primeiro grau julgou improcedente $o$ pedido por falta de provas, o que levou a genitora da criança a recorrer. Nos autos, ficou provado que houve imperícia e negligência médica no atendimento do parto o que levou ao relator a condenar o Estado ao pagamento de $\mathrm{R} \$ 25.000,00$ além do pagamento de 1,5 salário-mínimo até que a criança complete 65 anos.

Quanto à apelação Cível de $\mathrm{n}^{0}$ 001.2000.015746-9/001, ela foi um recurso impetrado pelo paciente contra o Instituto de Tisiologia e Pneumologia de Campina Grande Ltda. requerendo reforma da decisão de primeiro grau que considerou improcedente o pedido em face de falta de provas com relação a um suposto erro de diagnóstico que causou complicações para a saúde do autor. Entretanto, o recorrente ainda não conseguiu provar que o dano sofrido devido ao diagnóstico prévio errado estavam relacionados, não havendo, portanto, nexo de causalidade. Desta forma, o relator julgou improcedente o recurso.

A Apelação Cível de no 0000716 33.2006.815.0031 impetrada pela genitora da paciente em vista de danos morais e estéticos, incluindo cegueira no olho esquerdo, sofridos por ela devido a um acidente doméstico. 0 juiz de primeiro grau considerou o pedido improcedente porque não ficou provado o nexo de causalidade entre $o$ atendimento médico e o dano. A recorrente alega que o hospital de Alagoa Grande não possuía equipamento médico necessário para o seu tratamento. Contudo ficou provado que a cegueira adveio de uma infecção evoluída do trauma sofrido, além de que a genitora da menor não chegou a usar o colírio recomendado pelo médico recorrido. Logo, não ficou caracterizado erro médico, sendo considerado o recurso improcedente.

O paciente, o médico e o Hospital UNIMED de João Pessoa impetraram com apelações, resultando na Apelação Cível de $\mathrm{n}^{\mathrm{o}}$ 0004714-74.2010.815.2001. A inicial tratou de um erro cirúrgico, havendo perfuração de seu pulmão, que 
foi julgada parcialmente procedente no valor de $R \$ 30.000,00$, sendo $1 / 3$ da quantia a ser paga pelo médico e o resto do montante pelo hospital. 0 autor da inicial requereu aumento da condenação, enquanto que o médico e o hospital requerem ou a diminuição do valor ou que a demanda seja julgada improcedente. Ficou comprovada a culpa médica e, consequentemente a responsabilidade objetiva do hospital, contudo em vista da razoabilidade e proporcionalidade da indenização com o dano sofrido, o desembargador julgou pela manutenção da decisão originária.

$$
\text { A Apelação Cível no }
$$

200.2002.369334-0/001 impetrada pela autora da inicial contra os médicos e a UNIMED, pois seu pedido foi considerado improcedente em primeiro grau. Ela alega que o médico afirmou em primeiro diagnóstico que seu quadro de saúde era grave, o que fez com que ela entrasse em grande estresse e nervosismo. Ela realizou outro exame que negou o que o primeiro médico havia constatado. 0 relator do processo, contudo, adotou a teoria de que erros de diagnóstico são escusáveis a menos que sejam erros grosseiros, logo julgou improcedente a demanda.

A genitora do paciente, que foi a vítima de erro durante procedimento de parto na Clipsi, impetrou com a apelação Cível de no 001.1999.003825-7/001 para reformar a sentença de primeiro grau que considerou improcedente o pedido. A genitora alega que houve erros durante seu parto, como infecção, sofrimento fetal agudo, ausência de oxigenação de sangue e cesariana tardia, dentre outros danos. Após analisar as provas, o relator decidiu por condenar a clínica em $\mathrm{R} \$$ 100.000,00.

A Apelação Cível de $\mathrm{n}$ ㅇ 200.2005.002624-0/001 abordou o tema de um suposto erro médico em uma cirurgia para tratamento de cálculo renal. A impetrante deste recurso foi a paciente contra a Clínica Santa Cruz a fim de reformar a sentença de primeiro grau que julgou improcedente $\mathrm{o}$ pedido. 0 relator julgou o recurso improcedente porque os danos sofridos não resultaram de culpa ou dolo do médico, pois sua obrigação era de meio, ou seja, de usar as melhores técnicas sem erros, e não de resultado, garantir a cura.

A Apelação Cível $\mathrm{n}^{\circ}$ 001.2001.006443-2/001 foi realizada pela Clipsi para reformar a sentença atacada que a condenou no montante de $\mathrm{R} \$ 150.000,00$ em face de um erro cometido por um médico da clínica que mandou imobilizar a perna da autora da inicial sem realizar exames de raio-X ou outro exame. Ela retornou diversas vezes a mesma clinica para solucionar as dores que sofria, mas os médicos não realizaram os exames nem ajudaram de forma correta a paciente. Ela foi ser atendida em Recife, onde foi constatada a irreversibilidade do problema e teve que ter sua perna amputada. Apesar de ser irrefutável a prova do erro médico, o relator julgou pelo provimento parcial do recurso para $\mathrm{R} \$ 65.000,00 \mathrm{de}$ indenização em virtude do valor originário não condizer com a realidade jurisprudencial e existencial.

A Clipsi também impetrou com a Apelação Cível no 0012004021941 0/001 para reformar a sentença originária que a condenou ao pagamento de 50 salários-mínimos, equivalendo a $\mathrm{R} \$$ 13.000,00, de indenização devido a uma histerectomia parcial, que impossibilitou a apelada de engravidar novamente, pelo fato de não ter sido devidamente assistida pelo médico responsável. Após análise das provas, o desembargador julgou pela manutenção do valor da indenização da sentença atacada em virtude de comprovada a culpa médica e responsabilidade objetiva da clínica além de que o valor serve de base para desestimular os profissionais a agirem de forma desidiosa.

A Apelação Cível de $\mathrm{n}$ o 888.2004.006938-8/001 foi impetrada pelo médico em face de uma decisão de primeira instância que o condenou ao pagamento de 200 salários-mínimos a titulo de dano moral e $\mathrm{R} \$ 3.000,00$ a 
título de dano material devido a um erro ocorrido durante uma cirurgia plástica de abdômen e de face. 0 relator traz a teoria já mencionada que cirurgias plásticas embelezadoras impõem uma obrigação de resultado, enquanto que as reparadoras impõem uma obrigação de meio. 0 caso em tela foi de uma cirurgia embelezadora que resultou em graves sequelas. 0 relator, apesar de ter julgado pela culpa do médico diante das provas, julgou pela procedência parcial do recurso, reduzindo o valor da indenização para $\mathrm{R} \$ 33.000,00$.

Quanto à Apelação Cível $\mathrm{n}^{\text {o }}$ 888.2004.010500-7/001, ela foi realizada pelo Laboratório Adolpho Lutz em face do autor da inicial, que foi considerada procedente e condenou $\mathrm{o}$ promovido. Tal ação versou sobre um erro de diagnóstico de exame que indicava a presença de dois bacilos por campo, o que levou o autor a acreditar estar com tuberculose, o que não era o caso. Contudo, ficou provado que o laboratório não incorreu em erro e que o diagnóstico errado foi fruto de culpa exclusiva de terceiro, o que levou o relator a julgar procedente o recurso.

A Apelação Cível $\mathrm{n}$ 001.2002.004.908-4 versou sobre uma decisão de primeira instância que condenou o médico ao pagamento de $\mathrm{R} \$$ $10.000,00$ referentes a uma cirurgia de vasectomia mal sucedida que resultou na gravidez da esposa do autor da inicial. 0 relator salientou que tal procedimento tem a responsabilidade em cima do resultado e não de meio, pois seu objetivo não era cuidar de algum mal que afligisse a saúde dele. Por esta razão, o desembargador julgou pela improcedência do recurso do médico e manteve o valor da indenização de primeiro grau.

Apelação Cível de no 001.2003.010082-8/001 foi impetrada pelo paciente em face do médico e da Oftalmologia Saulo Freire Ltda. porque o apelante realizou uma cirurgia de catarata e sofreu eventual cegueira no olho esquerdo. Contudo a ação inicial foi julgada improcedente sob a alegação de que o paciente não seguiu as instruções médicas resultando na perda da visão. Segundo os peritos, todo o procedimento médico foi correto, sendo a culpa realmente do apelante, logo, por esta razão, o recurso foi julgado improcedente.

Quanto à apelação Cível de $\mathrm{n}^{0}$ 888.2004.009489-7/001 ela foi um recurso impetrado pelo autor da inicial em face do Hospital Central de Campina Grande devido a improcedência da petição inicial. Tal caso aborda um procedimento cirúrgico que terminou em óbito do cônjuge do autor da inicial que requereu a responsabilidade objetiva do médico. Contudo, como já explicado, a responsabilidade do profissional é subjetiva. Assim, o relator julgou improcedente o recurso em vista de que não foi apurada nenhuma prova de negligência, imprudência ou imperícia por parte do médico ou do hospital.

Por fim, o último caso estudado é o da Apelação Cível de $\mathrm{n}^{\text {o }}$ 888.2004.011804-4/001 que tratou de um recurso impetrado pelo Hospital Pedro I em face da autora da inicial que realizou uma laqueadura de trompas mal sucedida que resultou na sua gravidez. 0 juiz a quo condenou o hospital ao pagamento de 100 salários-mínimos, sendo o médico responsável por $20 \%$ do valor e o hospital $80 \%$. O hospital alega que a apelada não procurou seus serviços para fazer laqueadura de trompas, mas, sim, apendicectomia, apresentando exames de sangue como prova. Contudo, ficaram provadas a negligência e imperícia médicas, pois a paciente provou que realmente veio fazer laqueadura de trompas e dos riscos que sua gravidez apresentava. 0 relator, contudo, deu provimento parcial ao recurso reduzindo o valor da condenação para $R \$ 15.000,00$, a ser dividido na mesma proporção que o juiz de primeiro grau fixou. 


\section{Interpretação dos casos}

Foram estudados 47 recursos que foram impetrados entre o ano de 1998 a 2010. Desse total, 28 deles houve a condenação do médico ou hospital, enquanto que, em 19 deles, não houve condenação, seja pela absolvição do médico, hospital ou clínica ou devido ao rejulgamento do processo.
Além disso, houve uma distribuição de processos impetrados de forma bastante dispersa no Tribunal de Justiça da Paraíba, sendo o maior número pertencente a 2005, seguido de 2004 . Valendo lembrar que tais anos são referentes ao ano em que o recurso foi impetrado e não da data de julgamento. Sendo 1998, 2008, 2009 e 2010 com o menor número de casos (Figura 1).

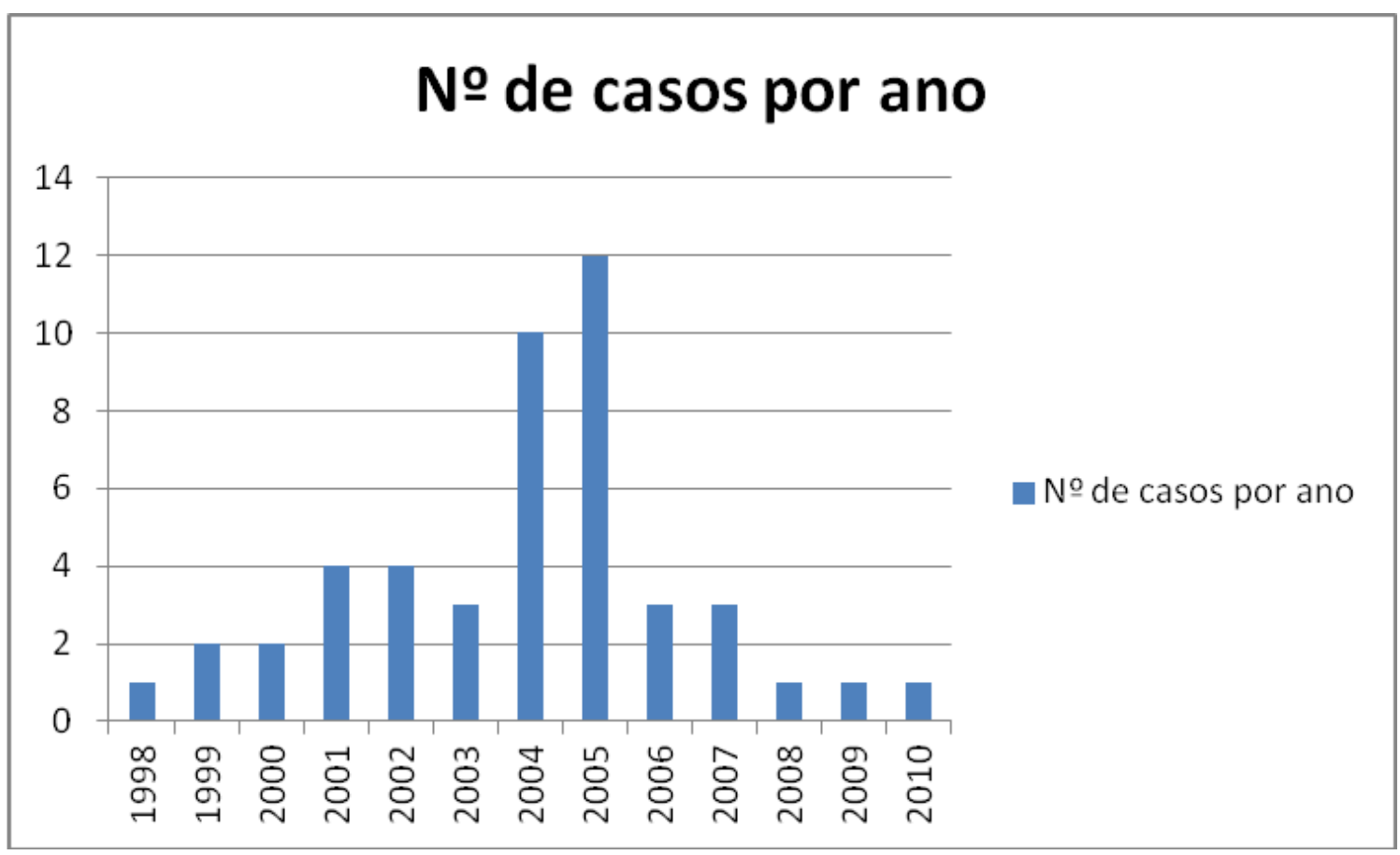

Figura 1. Distribuição de recursos por ano.

Por fim, pode-se constatar que a maior parte das indenizações está concentrada na faixa entre $\mathrm{R} \$ 10.001,00$ e R \$50.000,00 (Figura 2), totalizando 16 casos $(57 \%)$ dentre os 28 . Percebe-se que há certa relutância em manter um valor alto em alguns casos principalmente para se evitar o chamado "enriquecimento sem causa". Enquanto que é importante evitar tal fato, deve-se levar em conta que a saúde e o bem-estar físico de uma pessoa não possuem um preço. Ninguém pode propor algo como "perder uma perna garante o direito a $\mathrm{X}$ reais se o médico possuiu culpa". 


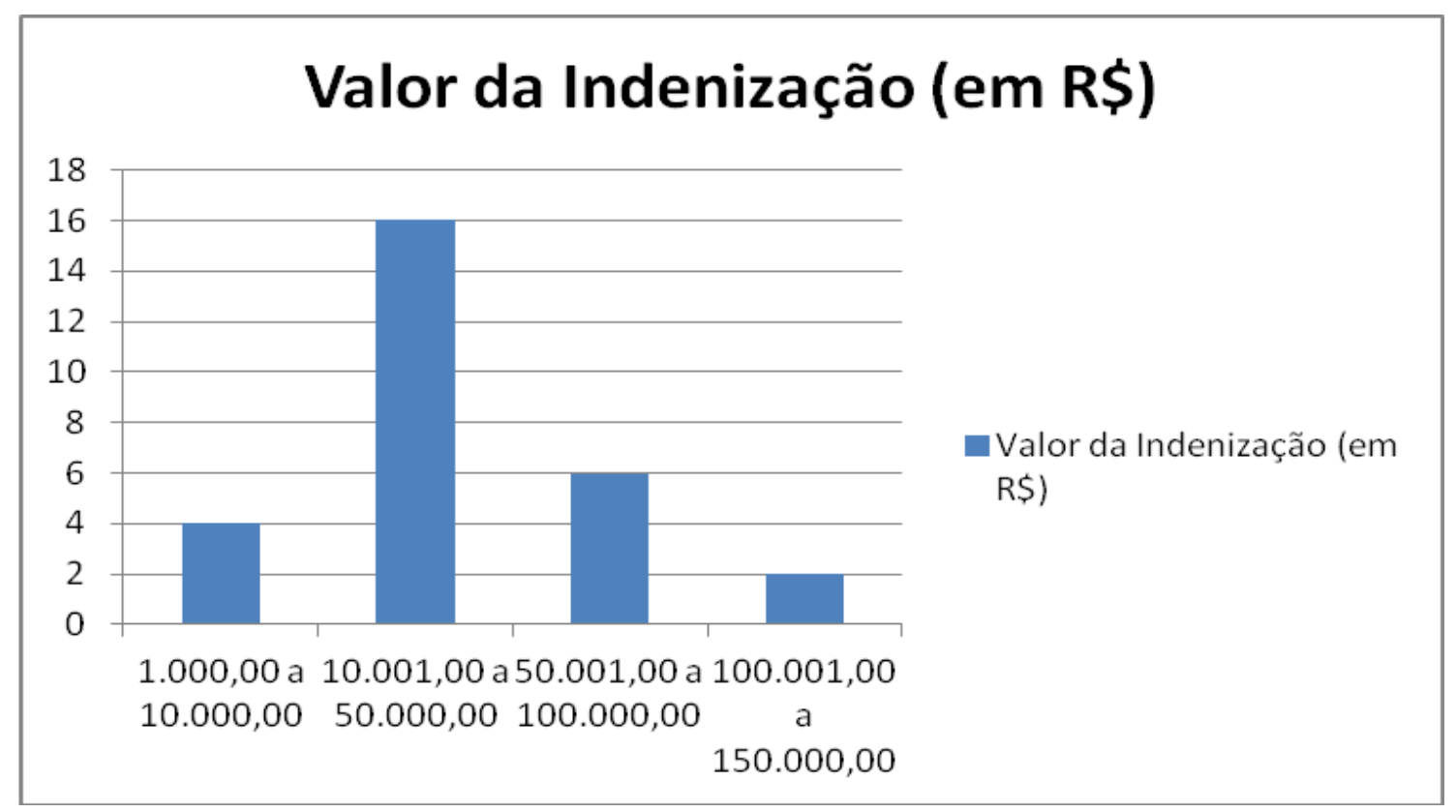

Figura 2. Percentual de casos para cada faixa de indenização.

\section{Conclusão}

Entende-se que médicos são seres humanos como qualquer outro profissional e como humanos, estão sujeitos a erros. Esse profissional da área de saúde não está propenso a mais ou a menos erros que os outros. Contudo, médicos lidam com o bem jurídico mais valioso para qualquer pessoa, a vida.

Pacientes vão aos médicos porque necessitam deles para recuperar sua saúde. Há certo grau de confiança de que o tratamento aplicado pelo médico irá curar a enfermidade, ou, pelo menos servir de paliativo, a depender do problema de saúde, pois nem todas as doenças possuem cura seja por sua natureza, seja pelo estágio em que se encontra graças a uma identificação tardia.

Contudo, por mais humano que seja, um erro médico pode causar danos permanentemente ou não às pessoas. Por esta razão, dependendo do caso, médicos devem ser punidos para que sirva de lição tanto para ele, quanto para outros colegas, de que o bem de que eles cuidam merecem toda a sua atenção e cuidado.
Dentre os casos estudados, em grau de recurso no Tribunal de Justiça da Paraíba, houve uma maioria de $60 \%$ de condenações de médicos, hospitais e clínicas. Do total, 12 casos foram impetrados em 2005, seguido por 10 casos em 2004. Além disso, apenas dois processos tiveram valores superiores ao montante de $\mathrm{R} \$ 100.001,00$, o que possui dois lados, um positivo e um negativo.

0 positivo diz que há realmente um trabalho dedicado dos relatores para se evitar dar indenizações quando não há a presença de culpa ou dolo por parte dos médicos. Contudo, há também o lado negativo, pois houve certas diminuições no valor de indenizações com o intuito de se evitar o enriquecimento sem causa, porém tais decisões não levaram em conta que, nesses casos, o paciente ou recebeu graves dano a sua saúde ou possuiu perda de alguma parte ou função do corpo.

Portanto, espera-se que, no futuro, as condenações sejam o reflexo o mais perto do ideal possível para tentar se reparar o dano, afinal a vida e a saúde não podem ser quantificados economicamente. Levando-se em conta, 
também, a capacidade econômica do médico, hospital ou clínica, pois não se pode exigir um valor demasiadamente elevado, o que causaria graves danos a eles, mas também não se pode impor um valor irrisório perante o patrimônio que eles possuem. Afinal, uma das características das condenações é educar para que tais erros não mais aconteçam.

\section{Conflito de interesses}

0 autor declara não haver conflito de interesses.

\section{Referências}

Brasil. Decreto no 20.931, de 11 de janeiro de 1932. Regula e fiscaliza o exercício da medicina, da odontologia, da medicina veterinária e das profissões de farmacêutico, parteira e enfermeira, no Brasil, e estabelece penas. Disponível em: <http://www.planalto. gov.br/ccivil_03/decreto/1930-1949/ D20931.htm>. Acesso em: 07 jul. 2018.

Brasil. Decreto-Lei no 2.848 , de 7 de dezembro de 1940. Código Penal. Disponível em: <http://www.planalto.gov. br/ccivil_03/decreto-lei/Del2848 compilado.htm>. Acesso em: 07 jul. 2018.

Brasil. Lei no 8.078, de 11 de setembro de 1990. Dispõe sobre a proteção do consumidor e dá outras providências. Disponível em: <http://www.planalto.gov. br/ccivil_03/LEIS/L8078compilado.htm>. Acesso em: 07 jul. 2018.

Brasil. Lei no 8.080, de 19 de setembro de 1990. Dispõe sobre as condições para a promoção, proteção e recuperação da saúde, a organização e o funcionamento dos serviços correspondentes e dá outras providências. Disponível em: <http://www.planalto.gov. br/ccivil_03/LEIS/L8078.htm>. Acesso em: 07 jul. 2018.
Brasil. Lei no 8.112, de 11 de dezembro de 1990. Dispõe sobre o regime jurídico dos servidores públicos civis da União, das autarquias e das fundações públicas federais. Disponível em: <http://www.planalto.gov. br/ccivil_03/LEIS/L8112compilado.htm>. Acesso em: 07 jul. 2018.

Brasil. Lei no 10.406, de 10 de janeiro de 2002. Institui o Código Civil. Disponível em: <http://www.planalto.gov.br/ccivil_03/LEIS /2002/L10406compilada.htm>. Acesso em: 07 jul. 2018.

Brasil. Lei no 13.105, de 16 de março de 2015. Código de Processo Civil. Disponível em: <http://www.planalto.gov.br/ccivil_03/ _Ato2015-2018/2015/Lei/L13105.htm>.

Acesso em: 10 jan. 2019.

Fávero F. Deontologia médica e medicina profissional. São Paulo: Livraria Martins Editora, 1945.

Gomes, J. C. M. Erro médico: reflexões. Revista Bioética, v. 2, n. 2, 1994. Disponível em: $\quad$ http://revistabioetica.cfm.org.br/ index.php/revista_bioetica/article/view/459 /342>. Acesso em: 07 jul. 2018.

Hammurabi. Hammurabi Code. Disponível em: <http://www.dhnet.org.br/direitos/ anthist/hamurabi.htm>. Acesso em: 14 jul. 2018.

Moraes, N. C. Erro médico: aspectos jurídicos. Brazilian Journal of Cardiovascular Surgery, v. 11, n. 2, p. 55-59, 1996. https://doi.org/10.1590/S0102-763819960 00200002

Nunes, J. A. Erro médico. Rio de Janeiro: Universidade Candido Mendes, 2004. (Monografia de pós-graduação lato sensu). Disponível em: <http://www.avm.edu.br/ monopdf/35/JULIANA ANDRADE NUNES.pdf >. Acesso em: 14 jul. 2018. 